\title{
KONSTITUSIONALITAS PERLINDUNGAN PETAMBAK GARAM MELALUI REGULASI DAERAH
}

\section{Constitutionality of Salt Farmer's Protection Through Local Regulation}

\author{
*Encik Muhammad Fauzan, Indra Yulianingsih, dan Azizah \\ Fakultas Hukum Universitas Trunojoyo Madura \\ Jl. Raya Telang, Perumahan Telang Inda, Kabupaten Bangkalan, Jawa Timur 69162, Indonesia \\ Diterima tanggal: 29 November 2019; Diterima setelah perbaikan: 29 Mei 2020; \\ Disetujui terbit: 25 Juni 2020
}

\begin{abstract}
ABSTRAK
Pemerintah telah membentuk peraturan terkait perlindungan dan pemberdayaan petambak garam melalui Undang-Undang Nomor 7 Tahun 2016. Undang-undang ini perlu ditindak lanjuti dalam bentuk produk hukum dan kebijakan daerah agar petambak garam dapat merasakan manfaat dari peraturanperaturan tersebut. Pada kenyataannya masih sangat sedikit daerah yang membentuk peraturan daerah (perda) untuk mewujudkan amanat undang-undang ini. Tujuan penelitian ini yaitu untuk menganalisis dan memberikan dasar perlindungan secara konstitusional bagi petambak garam dan mengetahui regulasi yang harus dibentuk pada tingkat daerah. Kajian ini menggunakan metoda penelitian hukum doktrinal dengan pendekatan perundang-undangan. Pola analisis yang digunakan dengan cara deduktif yang dimulai dari Undang-Undang Dasar Negara Republik Indonesia Tahun 1945 (UUD NRI Tahun 1945). Hasil penelitian ini adalah perlindungan dan pemberdayaan petambak garam telah ada secara tersirat dalam UUD NRI Tahun 1945 sebagai bentuk konstitusionalitas. Bentuk regulasi yang harus dibentuk oleh pemerintah daerah yaitu peraturan daerah, peraturan kepala daerah dan kebijakan lain. Penelitian ini merekomendasikan daerah-daerah yang mempunyai tambak garam untuk membentuk regulasi tersebut yaitu peraturan daerah terkait perlindungan dan pemberayaan petambak garam dan peraturan kepala daerah seperti peraturan bupati terkait pedoman teknis pelaksanaan perlindungan dan pemberdayaan petambak garam, dan optimalisasi industri garam lokal serta kebijakan daerah terkait tim pelaksana pemberdayaan petambak garam.
\end{abstract}

Kata Kunci: konstitusionalitas; perlindungan; pemberdayaan; petambak garam; regulasi

\begin{abstract}
The government has established regulations related to the protection and empowerment of salt farmers through Law Number 7 of 2016. This law needs to be realized in the form of regional legal and other regional policies in order that salt farmers can benefit from this regulation. In fact, very few regions have formed local laws (perda) to realize the mandate of this law. The purpose of this study is to analyze and provide a basis for constitutional protection for salt farmers and determine the regulations that must be established at the regional level. This study uses doctrinal legal research with a statutory approach. The pattern of analysis used in a deductive way starting with the 1945 Constitution of the Republic of Indonesia (UUD NRI Tahun 1945). The results in this study are the protection and empowerment of salt farmers already implied in the 1945 Constitution of the Republic of Indonesia as a form of constitutionality. The form of regulations that must be formed by the regional government are regional regulations, regional head regulations and other policies. This study recommends areas that have salt ponds to form such regulations, namely local laws related to the protection and empowerment of salt farmers and regional head regulations such as regent regulations related to technical guidelines for the implementation of protection and empowerment of salt farmers, and optimization of the local salt industry and regional policies related to the team executor of empowering salt farmers.
\end{abstract}

Keywords: constitutionality; protection; empowerment, salt farmers; regulation 


\section{PENDAHULUAN}

Indonesia mempunyai panjang pantai sepanjang $95.181 \mathrm{~km}$ dan memiliki potensi air laut yang baik sebagai bahan dasar pembuatan garam (natrium klorida). Potensi ini masih belum dimaksimalkan sehingga Indonesia masih mengimpor garam dari negara lain. Kebutuhan garam nasional dari tahun ke tahun semakin meningkat seiring dengan pertambahan penduduk dan perkembangan industri di Indonesia (Rusiyanto, Soesilowati, \& Jumaeri, 2013). Berdasarkan data dari Kementerian Perindustrian (Kemenperin) kebutuhan garam industri tahun 2018 mengalami kelonjakan jumlah kebutuhannya yang mencapai 3.700 .000 juta ton naik $76,19 \%$ dari kebutuhan tahun 2017 yang jumlahnya 2.100.000 (Pangestu, 2018). Impor garam merupakan salah satu solusi untuk memenuhi kebutuhan itu. Ketergantungan impor terparah dialami oleh garam industri karena spesifikasi yang dibutuhkan belum dapat dipenuhi oleh sentra-sentra produksi garam di dalam negeri.

Pemenuhan kebutuhan garam nasional memang sudah seharusnya mendapatkan perhatian khusus dari pemerintah karena sampai dengan hari ini, pemenuhan kebutuhan garam nasional belum dapat dilakukan secara swasembada (Pangestu, 2018). Pemerintah mengeluarkan regulasi terkait impor garam melalui Peraturan Menteri Perdagangan Republik Indonesia Nomor 63 Tahun 2019 tentang Ketentuan Impor Garam (Permendag RI No.63/2019). Berdasarkan Pasal 2 sampai Pasal 5 Permendag RI No. 63/2019, dijelaskan bahwa garam yang dapat diimpor merupakan garam untuk pemenuhan bahan baku dan bahan penolong industri dan memiliki standar mutu berupa kandungan natrium klorida $97 \%$ atau lebih tetapi kurang dari $100 \%$, dihitung dari basis kering dan hanya dapat diimpor oleh perusahaan pemilik NIB (Nomor Induk Berusaha) yang berlaku sebagai API-P (Angka Pengenal Importir Produsen) yang telah mendapat persetujuan impor garam dari Menteri.

Berdasarkan jenisnya, garam dibagi dalam dua kelompok besar, yakni garam konsumsi dan garam industri, sedangkan berdasarkan pada kandungan natrium klorida $(\mathrm{NaCl})$, garam dibagi dalam empat kelompok, yakni menjadi garam pengawetan ikan, garam konsumsi, garam industri, serta garam farmasi (untuk keperluan infus, shampo, dan cairan dialisat) (Mustofa, 2015). Garam industri adalah garam yang digunakan sebagai bahan baku dalam proses produksi di sejumlah sektor bisnis, antara lain industri kimia, aneka pangan, farmasi, perminyakan, penyamakan kulit, dan pemeliharaan air. Oleh karena itu, garam merupakan salah satu komoditi yang secara terus menerus dibutuhkan oleh seluruh masyarakat. Fungsinya dalam memberi cita rasa asin pada makanan tidak dapat digantikan sehingga garam, khususnya garam konsumsi, menjadi produk yang memiliki sifat strategis. Hal ini yang menjadi penyebab bahwa garam konsumsi menjadi sensitif secara politis karena dapat mempengaruhi ketahanan nasional, sehingga hampirseluruh negara berusaha mencukupi sendiri kebutuhan garam konsumsi walaupun tidak layak secara ekonomi (Herman, Noor, \& Mulyadi, 2014). Oleh karena itu, kebutuhan garam yang semakin meningkat setiap tahunnya ini menjadi kesempatan bagi industri garam untuk meningkatkan produksinya sehingga mampu juga meningkatkan perekonomian dan status sosial para petambak garam.

Petambak garam belum mampu menghasilkan garam secara maksimal, sehingga perlu dukungan pemerintah melalui kebijakankebijakan pemerintah baik tingkat pusat dan tingkat daerah. Pemerintah juga sudah mengeluarkan peraturan perundang-undangan terkait garam seperti Undang-Undang Nomor 7 Tahun 2016 tentang Perlindungan dan Pemberdayaan Nelayan, Pembudi Daya Ikan, dan Petambak Garam (UU No. 7/2016), Peraturan Pemerintah Nomor 9 Tahun 2018 tentang Tata Cara Pengendalian Impor Komoditas Pergaraman, dan Peraturan Menteri Perindustrian Nomor 34 Tahun 2018 tentang Tata Cara Pemberian Rekomendasi Impor Komoditas Pergaraman sebagai Bahan Baku dan Bahan Penolong Industri. Selain itu, terdapat berbagai peraturan perundang-undangan yang terkait dengan pergaraman antara lain Undang-Undang Nomor 27 Tahun 2007 tentang Pengelolaan Wilayah Pesisir dan Pulau Pulau Kecil, yang telah mengalami perubahan menjadi Undang-Undang Nomor 1 Tahun 2014 dan Undang-Undang Nomor 23 Tahun 2014 tentang Pemerintahan Daerah.

Peraturan perundang-undangan yang telah ada ternyata belum mampu mengeluarkan Indonesia dari permasalahan garam. Salah satu penyebab hal ini adalah kurangnya kepedulian pemerintah daerah terhadap potensi garam yang ada di daerahnya. Hal ini dapat dilihat dari minimnya produk hukum daerah dan kebijakankebijakan daerah terkait garam yang dibentuk oleh pemerintah daerah yang memiliki tambak garam. 
Seperti di Pulau Madura yang dikenal sebagai Pulau Garam, ternyata sangat minim produk hukum daerah dan kebijakannya terkait garam dibentuk. Oleh karena itu riset ini mengambil studi kasus di empat kabupaten yang ada di Pulau Madura, yang merupakan sentral garam Indonesia. Sebagian besar lahan tambak garam yang tersebar di Pulau Jawa, hampir 95\%-nya berada di Madura (Prihantini, Syaukat, \& Fariyanti, 2016).

Minimnya regulasi dan kebijakan yang terbentuk di daerah yang mempunyai tambak garam merupakan pengabaian atas hak petambak garam yang dilindungi oleh UndangUndang Dasar Negara Republik Indonesia Tahun 1945 (UUD NRI Tahun 1945). Berdasarkan hal tersebut maka memunculkan pernyataan masalah bagaimanakah UUD NRI Tahun 1945 dalam menjamin dan melindungi hak-hak petambak garam dan bagaimanakah bentuk penerapan produk hukumnya di daerah. Tujuan penelitian ini yaitu untuk menganalisis dan memberikan dasar perlindungan secara konstitusional bagi petambak garam dan dan mengetahui regulasi yang harus dibentuk pada tingkat daerah.

Penelitian ini merupakan penelitian hukum doktrinal yang merupakan penelitian dengan memberikan paparan yang sistematis tentang peraturan yang mengatur pada kategori hukum tertentu, menganalisis hubungan antara peraturan, menjelaskan pada bidang yang sulit serta memprediksi perkembangan pada masa depan (Hutchinson, 2006). Penelitian ini mencari suatu asas hukum, kaedah hukum dalam arti nilai (norm), peraturan hukum konkrit dan sistem hukum (Mertokusumo, 2001). Tujuan dari penelitian hukum doktrinal adalah mengkaji apakah suatu kaidah hukum dianggap sudah cukup mewadahi aspirasi masyarakat yang ada, mengkaji instrumen hukum yang diperlukan masyarakat, menguji keberlakukan jalannya suatu peraturan perundangundangan. Manfaat dari penelitian hukum doktrinal antara lain: memberikan masukan berkaitan dengan peraturan perundang-undangan yang ada serta diharapkan dapat menjadi sarana kontrol atau perubahan perilaku.

Pendekatan yang digunakan dalam penelitian ini adalah pendekatan penelitian perundangan-undangan yaitu merupakan penelitian yang mencoba menggali apakah perundang-undangan yang ada telah dilaksanakan secara baik dan benar oleh pihak pihak pemegang peran dalam perundang-undangan tersebut
(Yaqin, 2007). Selain itu pendekatan ini pun bertujuan mengidentifikasi permasalahan yang muncul ketika secara normatif telah diatur namun masih sukar untuk melaksanakan nilai-nilai normatif tersebut, sehingga dapat menentukan apakah perundang-undangan tersebut perlu direvisi atau tidak (Yaqin, 2007).

Perundang-undangan yang digunakan untuk analisis adalah UUD NRI Tahun 1945. Undang Undang Dasar ini sebagai bahan hukum primer untuk memecahkan masalah atas konstitusionalitas perlindungan petambak garam melalui produk hukum daerah dan kebijakan daerah. Bahan hukum primer merupakan bahan hukum yang mengikat dan terdiri dari norma atau kaedah dasar, yaitu Pembukaan UUD NRI Tahun 1945, Peraturan Dasar yaitu batang tubuh UUD NRI Tahun 1945, peraturan perundang-undangan, bahan hukum yang tidak dikodifikasikan, dan yuriprudensi (Amiruddin \& Zainal, 2012). Selain UUD NRI Tahun 1945, bahan hukum primer yang digunakan dalam analisis ini adalah berbagai peraturan perundang-undangan lainnya yang kedudukannya di bawah UUD NRI Tahun 1945 yaitu undang-undang, peraturan pemerintah, peraturan presiden, dan peraturan daerah.

Selain bahan hukum primer, penelitian ini pun menggunakan bahan hukum sekunder dalam analisis riset. Bahan hukum sekunder, yaitu bahan yang memberikan penjelasan mengenai bahan hukum primer seperti rancangan undang-undang, hasil-hasil penelitian, atau pendapat para pakar hukum (Amiruddin \& Zainal, 2012). Bahan hukum sekunder yang digunakan dalam riset ini berasal dari jurnal-jurnal ilmah terkait dengan kebijakan pergaraman.

Analisis dalam penelitian ini menggunakan pola deduktif yaitu membahas dari aspek konstitusi terlebih dahulu terhadap hak perlindungan petambak garam. Pola analisis deduktif ini merupakan penalaran hukum bertolak dari aturan hukum yang berlaku umum ke aturan hukum yang berlaku khusus (Suratman \& Dillah, 2012). Hasil analisis tersebut dituangkan dalam suatu pembahasan yang sistematis sehingga menghasilkan suatu kajian penelitian yang dapat memberikan solusi atas perlindungan petambak garam. Setelah menganalisis dari aspek konstitusionalitasnya, maka dilakukan kajian terhadap peraturan perundang-undangan yang telah dibentuk oleh pemerintah baik pada tingkat pusat maupun daerah. 


\section{KONSTITUSIONALITAS PERLINDUNGAN PETAMBAK GARAM}

UUD NRI Tahun 1945 merupakan hukum dasar tertulis di Indonesia untuk menyelenggarakan kekuasaan negara. Penyelenggaraan kekuasaan negara merupakan pelaksanaan fungsi-fungsi negara dan pemerintahan negara yang telah diatur dalam UUD NRI Tahun 1945. Selain itu, UUD NRI Tahun 1945 sebagai konstitusi mengatur hubungan di antara lembaga-lembaga negara, antara lembaga negara dengan rakyatnya, dan rakyat dengan rakyatnya dalam pelaksanaan kedaulatan rakyat. Kedaulatan rakyat telah diatur dalam Pasal 1 ayat (2) yang menyatakan "Kedaulatan berada di tangan rakyat dan dilaksanakan menurut Undang-Undang Dasar".

Negara dalam membentuk konstitusi selain melaksanakan kedaulatan rakyat juga untuk memberikan dasar tujuan negara yang ada dalam Pembukaan UUD NRI Tahun 1945. Tujuan pembentukan negara tersebut salah satunya adalah mewujudkan kesejahteraan umum. Keberadaan konstitusi yang harus ada pada setiap negara mempunyai tujuan, yaitu: (1) Membatasi kekuasaan penguasa agar tidak bertindak sewenang-wenang; (2) Adanya perlindungan hak asasi manusia, dan; (3) Pedoman penyelengaraan negara untuk mengatur tata tertib bernegara terkait dengan berbagai lembaga-lembaga negara dengan wewenang dan cara bekerjanya, hubungan antarlembaga negara, dan hubungan lembaga negara dengan warga negara (Fauzan, 2016).

Ketentuan-ketentuan yang ada dalam UUD NRI Tahun 1945, wajib dilaksanakan oleh semua unsur yang ada di dalam negara termasuk pemerintah daerah dan petambak garam. Ketentuan-ketentuan ini menjadi dasar terlaksananya perlindungan bagi warga negara yang disebut sebagai konstitutisionalitas terhadap semua unsur yang ada dalam negara. Menurut Hans Kelsen, konstitusionalitas adalah keabsahan berdasarkan prosedur konstitusi (Arato, 2012) atau merupakan validitas norma-norma sesuai dengan konstitusi. Hal ini dapat dimaknai lebih lanjut bahwa konstitusionalitas merupakan keabsahan berdasarkan prinsip, makna dan prosedur berdasarkan konstitusi.

Pasal 25A UUD NRI Tahun 1945 menyatakan bahwa Negara Kesatuan Republik Indonesia adalah sebuah negara kepulauan yang bercirikan Nusantara dengan wilayah yang batas-batas dan hak-haknya ditetapkan dengan undang-undang.
Pasal 25A UUD NRI Tahun 1945 ini kemudian melahirkan dua undang-undang yang dibentuk oleh pemerintah, yaitu Undang-Undang Nomor 43 Tahun 2008 tentang Wilayah Negara (UU No. 43/2008) dan Undang-Undang Nomor 32 Tahun 2014 tentang Kelautan (UU No. 32/2014). Lahirnya UU No. 43/2008, dengan beberapa pertimbangan yakni: (1) Negara Kesatuan Republik Indonesia sebagai negara kepulauan yang berciri nusantara mempunyai kedaulatan atas wilayahnya serta memiliki hak-hak berdaulat di luar wilayah kedaulatannya dan kewenangan tertentu lainnya untuk dikelola dan dimanfaatkan sebesar-besarnya bagi kesejahteraan dan kemakmuran rakyat Indonesia sebagaimana diamanatkan dalam UUD NRI Tahun 1945; (2) Pengaturan mengenai wilayah negara meliputi wilayah daratan, perairan pedalaman, perairan kepulauan dan laut teritorial beserta dasar laut, dan tanah di bawahnya, serta ruang udara di atasnya, termasuk seluruh sumber kekayaan yang terkandung di dalamnya, dan; (3) Pengaturan wilayah negara tersebut dilakukan untuk memberikan kepastian hukum dan kejelasan kepada warga negara mengenai ruang lingkup wilayah negara, kewenangan pengelolaan wilayah negara, dan hak-hak berdaulat. Berdasarkan pertimbangan tersebut negara berkepentingan untuk ikut mengatur pengelolaan dan pemanfaatan di laut bebas dan dasar laut internasional sesuai dengan hukum internasional (Zein, 2016).

$$
\text { Lahirnya UU No. 32/2014 }
$$

mempertimbangkan, yaitu: (1) Negara Kesatuan Republik Indonesia sebagai negara kepulauan memiliki sumber daya alam yang melimpah yang merupakan rahmat dan karunia Tuhan Yang Maha Esa bagi seluruh bangsa dan negara Indonesia yang harus dikelola secara berkelanjutan untuk memajukan kesejahteraan umum sebagaimana diamanatkan dalam Undang-Undang Dasar Negara Republik Indonesia Tahun 1945; (2) Wilayah laut sebagai bagian terbesar dari wilayah Indonesia yang memiliki posisi dan nilai strategis dari berbagai aspek kehidupan yang mencakup politik, ekonomi, sosial budaya, pertahanan, dan keamanan merupakan modal dasar pembangunan nasional, dan; (3) Pengelolaan sumber daya kelautan dilakukan melalui sebuah kerangka hukum untuk memberikan kepastian hukum dan manfaat bagi seluruh masyarakat sebagai negara kepulauan yang berciri nusantara (Magdalena, 2018).

Pertimbangan lahirnya kedua undang-undang di atas selain memperhatikan dasar konstitusional 
juga mempertimbangkan fakta geografis dan sumber daya yang dimiliki Indonesia. Hal ini sangat penting untuk menjadi dasar pengelolaan sumber daya kelautan dan alamnya bagi pemerintah maupun pemerintah daerah yang mempunyai kewenangan di dalamnya. Pasal 9 UU No. 43/2008 menyatakan pemerintah dan pemerintah daerah berwenang mengatur pengelolaan dan pemanfaatan Wilayah Negara dan Kawasan Perbatasan, dan Pasal 14 ayat (1) UU No. 32 Tahun 2014 yang menyatakan pemerintah dan pemerintah daerah sesuai dengan kewenangannya melakukan pengelolaan kelautan untuk sebesar-besarnya kemakmuran rakyat melalui pemanfaatan dan pengusahaan sumber daya kelautan dengan menggunakan prinsip ekonomi biru. Kedua undang-undang ini mempertegas adanya kewenangan pemerintah daerah dalam pengelolaan kelautan. Pasal 14 ayat (2) juga menjelaskan bahwa pemanfaatan sumber daya kelautan ini meliputi perikanan, energi dan sumber daya mineral, sumber daya pesisir dan pulau-pulau kecil, dan sumber daya non konvesional.

Pada penjelasan Pasal 14 ayat (1) UU No. 32/2014, menjelaskan bahwa ekonomi biru merupakan sebuah pendekatan untuk meningkatkan pengelolaan kelautan berkelanjutan serta konservasi laut dan sumber daya pesisir beserta ekosistemnya dalam rangka mewujudkan pertumbuhan ekonomi dengan prinsip-prinsip antara lain keterlibatan masyarakat, efisiensi sumber daya, meminimalkan limbah, dan nilai tambah ganda (double value added). Ketentuan ini mempunyai arti bahwa dalam pengelolaan sumber daya kelautan perlu memperhatikan faktor lingkungan dan peran serta masyarakat.

Uraian di atas, menegaskan bahwa Indonesia telah mendeklarasikan diri sebagai negara kepulauan yang mempunyai luas wilayah laut hampir 2/3 dari seluruh wilayah Indonesia. Laut yang kaya dengan sumber daya kelautannya perlu untuk dikelola secara baik oleh pemerintah pusat dan pemerintah daerah berdasarkan kewenangan yang diberikan berdasarkan perundang-undangan. Adapun tujuan pengelolaan sumber daya kelautan ini adalah untuk kemakmuran dan kesejahteraan rakyat. Sumber daya laut (hayati dan non hayati) terbagi atas menjadi 2 yaitu sumberdaya terbarukan (renewable resources), seperti perikanan dan hutan mangrove, dan sumberdaya tidak terbarukan (non renewable resources), seperti batu bara, minyak dan gas bumi, dan bahan tambang. Garam merupakan salah satu sumberdaya non hayati terbarukan. Pada air laut mengandung $86 \%$ natrium klorida $(\mathrm{NaCl})$ yang mempunyai peran penting dalam keseimbangan cairan, kontraksi otot, sistem saraf, dan berperan dalam distribusi cairan tubuh (Paweka, 2017).

Pengelolaan kelautan harus menggunakan prinsip ekonomi biru guna mewujudkan pertumbuhan ekonomi para pengelola sumber daya kelautan yaitu para nelayan dan petambak garam. Pengelolaan kelautan yang bertujuan untuk kemakmuran dan kesejahteraan ini selaras dengan Pasal 33 UUD NRI Tahun 1945 yang memberikan kewenanga kepada negara untuk mengelola sumber daya yang ada di bumi dan air untuk kepentingan kesejahteraan rakyat. Pasal 33 ayat (2) UUD NRI Tahun 1945 menyatakan bahwa "cabang-cabang produksi yang penting bagi negara dan yang menguasai hajat hidup orang banyak dikuasai oleh negara". Pada pasal 33 ayat (3) UUD NRI Tahun 1945 menyatakan "Bumi dan air dan kekayaan alam yang terkandung di dalamnya dikuasai oleh negara dan dipergunakan untuk sebesar-besar kemakmuran rakyat".

Kedua ayat ini memberikan isyarat bahwa kekayaan alam baik di darat maupun di laut harus dikelola oleh negara dan digunakan sebesar-besarnya untuk kemakmuran rakyat. Penguasaan oleh negara atas segenap sumber daya yang terdapat di dalam bumi, air, wilayah udara Indonesia serta segala kekayaan yang terkandung di dalamnya, haruslah dipergunakan hanya untuk sebesar-besarnya kemakmuran rakyat, bukan hanya kemakmuran untuk orang per orang. Tujuan akhir dari kegiatan ekonomi yang paling pokok, justru adalah terwujudnya ide masyarakat adil makmur berdasarkan Pancasila dan UUD NRI Tahun 1945. Manfaat dari adanya usaha pemanfaatan kekayaan alam yang tersedia itu adalah seluruh rakyat, rakyat banyak, dan termasuk rakyat setempat (Asshiddiqie, 2010).

Pada sisi yang lain pengelolaan sumber daya ini harus dikelola dengan mendasarkan pada demokrasi ekonomi dengan prinsip kebersamaan, efisiensi berkeadilan, berwawasan lingkungan, kemandirian serta menjaga keseimbangan kemajuan dan kesatuan ekonomi nasional. Dalam menjaga keseimbangan kemajuan dan kesatuan ekonomi nasional ini selaras dengan Pasal 18 UUD NRI Tahun 1945 dimana satuan-satuan ekonomi di seluruh wilayah Indonesia harus dilihat sebagai unit-unit yang terintegrasi secara 
nasional berdasarkan keadilan dan keselarasan satu dengan yang lain (Asshiddiqie, 2010). Artinya bahwa perkembangan setiap daerah tidaklah sama sehingga dalam penyusunan kebijakan ekonomi harus menyesuaikan dan melihat perkembangan perekonomian di masingmasing daerah atau wilayah tersebut.

Pulau Madura yang terkenal sebagai pulau garam merupakan area garam nasional dan penyumbang stok garam nasional terbesar, namun petambak garam belum dapat menikmati hasil dari garam tersebut. Beberapa kendala yang terus terjadi dari waktu ke waktu adalah rendahnya harga garam. Meskipun kondisi tersebut berlangsung sampai saat ini, pembuatan garam merupakan salah satu budaya masyarakat, sehingga mereka tidak pernah ingin berhenti memproduksi garam (Zainuri, Anam, \& Susanti, 2016). Salah satu kabupaten di Pulau Madura yaitu Kabupaten Pamekasan saat ini telah menjadi kawasan industri dari skala rumah tangga maupun multinasional. Kawasan tersebut terletak di Kecamatan Tlanakan, Galis, Pademawu, Pasean dan Batumarmar, dimana dalam proses pembuatan garam masih menggunakan cara tradisional dan memanfaatkan sinar matahari untuk proses penguapan yang terdiri dari tiga tahapan: pra produksi, proses produksi dan pasca produksi. Penanganan yang kurang baik pada daerah tersebut selama proses pembuatan garam akan menghasilkan garam dengan kualitas rendah. Pada saat pra produksi, tata lahan penggaraman perlu diperhatikan untuk menjamin hasil garam terbebas dari polutan (Samsiyah, Moelyaningrum, \& Ningrum, 2019).

Di Pulau Madura terdapat 4.572 tambak garam yang tersebar di tiga kabupaten yaitu: di Sampang terdapat 1.377 tambak garam, di Pamekasan 1.547 tambak garam, dan di Sumenep 1.648 tambak garam. Tambak ini membentang di sepanjang pantai selatan Madura dan di lokasi tersebut didirikan gudang-gudang garam yang namanya sesuai nama desanya. Sampang mempunyai gudang-gudang garam berada di daerah Pragung, Dangpandang, Pangarengan, dan Apaan. Pamekasan terdapat gudang garam yang terlentak di Mangunan, dan Capak. Sementara gudang garam di Sumenep terletak di Marengan, Palebunan, Pinggir Papas, dan Sarokan. Daerah pembuatan garam di pantai selatan itu di dukung oleh faktor alam yang hasil produksi garam memiliki kualitas baik. Pertama, air laut di pantai selatan mengandung kadar garam yang sangat tinggi. Kedua, daerah pantai selatan dilalui oleh angin gending (angin kencang tipe fohn yang berembus pada musim kemarau dan sifatnya panas serta kering). Oleh karena itu pengkristalan garam berlangsung sangat cepat (Parwoto, 2018).

Permasalahan yang muncul bahwa potensi garam yang besar pada wilayah Madura belum mampumenunjukkan perkembangan perekonomian yang signifikan dan bahkan nasib petambak garam juga kurang sejahtera. Contoh Kabupaten Pamekasan yang mempunyai produktivitas garam cukup tinggi, namun keuntungan yang diterima oleh petani garam masih rendah. Rendahnya pendapatan petani garam ini menyebabkan kurang sejahteranya petani. Penyebab utama rendahnya keuntungan yang diterima oleh petani garam karena masih banyaknya usaha garam yang dijalankan dengan sistem bagi hasil. Sistem bagi hasil yang umum dijalankan yaitu pola bagi dua (merdua) dan pola bagi tiga (mertelu). Kedua pola ini dijalankan dengan melihat kondisi lahan tambak garam yang dikerjakan oleh petani penggarap. Kebiasaan bagi hasil pada lahan garam yang kurang produkti dengan pola bagi hasil dua yaitu pembagian keuntungan dibagi dua antara pemilik dan penggarap lahan. Kesepakatan pola ini pun tidak tertulis hanya kesepakatan lesan tanpa diawali diskusi terlebih dahulu. Kondis lahan garam yang dikerjakan semakin baik, maka pola bagi hasil akan berubah secara sepihak dari pemilik lahan menjadi pola bagi hasil tiga (perbandingan 2:1) dari keuntungan (Prihantini, Syaukat, \& Fariyanti, 2017). Pola bagi hasil dan mekanisme kontrak yang tidak tertulis ini tidak berdasarkan prinsip keadilan. Dalam laporan yang disampaikan oleh Bupati Pamekasan, terdapat sekitar 70,5 \% petani garam di Kabupaten Pamekasan menerapkan sistem bagi hasil atau dikenal dengan istilah mantong. Sistem bagi hasil membuat pemilik lahan atau pemodal menjadi dominan dalam hal pemasaran dan permodalan. Hal inilah yang membuat sistem bagi hasil kurang memberikan keadilan kepada petani penggarap (Prihantini et al., 2016).

Petani garam atau petambak garam harus mendapat perlindungan akan hak-haknya. Ketidakadilan bagi petambak garam bertentangan dengan nilai-nilai konstitusional dalam UUD NRI Tahun 1945. Adapun nilai-nilai konstitusional dalam UUD NRI Tahun 1945 bagi petambak garam tersebut yaitu:

a. Pasal 25A UUD NRI Tahun 1945 terkait dengan hak pengelolaan laut berdasarkan 
aspirasi masyarakat dan adanya kewenangan pengelolaan laut oleh pemerintah dan pemerintah daerah sebagaimana telah diatur dalam Undang-Undang Nomor 32 Tahun 2014 tentang Kelautan.

b. Pasal 27 ayat (2) UUD NRI Tahun 1945 yang menyatakan bahwa "tiap-tiap warga negara berhak atas pekerjaan dan penghidupan yang layak bagi kemanusiaan. Berdasarkan hal ini, sistem bagi hasil yang merugikan petambak garam jelas bertentangan dengan pasal ini. Hak bagi hasil harus didasarkan pada penghidupan yang layak.

c. Pasal 28D ayat (2) UUD NRI Tahun 1945 yang menyatakan bahwa "setiap orang berhak untuk bekerja serta mendapat imbalan dan perlakuan yang adil dan layak dalam hubungan kerja". Ini berarti hak untuk mendapatkan imbalan dan perlakuan yang adil merupakan bagian dari hak petambak garam yang harus dilindungi. Petambak garam harus mendapat bagi hasil yang adil antara pemilik lahan dan petambak garam.

d. Pasal 33 UUD NRI Tahun 1945, ayat (2) menyatakan bahwa "cabang-cabang produksi yang penting bagi negara dan yang menguasai hajat hidup orang banyak dikuasai oleh negara". Ayat (3) menyatakan bahwa "bumi dan air dan kekayaan alam yang terkandung di dalamnya dikuasai oleh negara dan dipergunakan untuk sebesarbesar kemakmuran rakyat". Pada ayat (4) menyatakan bahwa "Perekonomian nasional diselenggarakan berdasar atas demokrasi ekonomi dengan prinsip kebersamaan, efisiensi berkeadilan, berkelanjutan, berwawasan lingkungan, kemandirian, serta dengan menjaga keseimbangan kemajuan dan kesatuan ekonomi nasional". Ini berarti pemerintah harus menggunakan segala potensi sumber daya alam termasuk dari sumber daya kelautan untuk kemakmuran masyarakat. Petambak garam sebagai bagian dari masyarakat tentunya juga berhak mendapatkan kesejahteraan dan kemakmuran. Oleh karena itu, negara yang mempunyai kewenangan mengelola sumber daya yang terkandung dalam bumi harus mengelola dengan baik demi kepentingan hajat hidup orang banyak.

Oleh karena itu, pemerintah juga telah mengeluarkan peraturan yang khusus melindungi petambak garam melalui Undang-Undang Nomor 7 Tahun 2016 (UU No. 7/2016) tentang Perlindungan dan Pemberdayaan Nelayan, Pembudi Daya Ikan, dan Petambak Garam. Undang-undang ini disusun dengan tujuan untuk:

a. Menyediakan prasarana dan sarana yang dibutuhkan dalam mengembangkan usaha;

b. Memberikan kepastian usaha yang berkelanjutan;

c. Meningkatkan kemampuan dan kapasitas Nelayan, Pembudi Daya Ikan, dan Petambak Garam; menguatkan kelembagaan dalam mengelola sumber daya Ikan dan sumber daya kelautan serta dalam menjalankan usaha yang mandiri, produktif, maju, modern, dan berkelanjutan; dan mengembangkan prinsip kelestarian lingkungan;

d. Menumbuhkembangkan sistem dan kelembagaan pembiayaan yang melayani kepentingan usaha;

e. Melindungi dari risiko bencana alam, perubahan iklim, serta pencemaran; dan

f. Memberikan jaminan keamanan dan keselamatan serta bantuan hukum.

Berdasarkan tujuan pembentukan UU No. 7/2016 ini, memberikan kewenangan kepada pemerintah pusat dan pemerintah daerah untuk penyelenggaraan perlindungan bagi petambak garam. Pasal 16 ayat(1)UU No. 7/2016, menyatakan "Pemerintah Pusat dan Pemerintah Daerah sesuai dengan kewenangannya bertanggung jawab atas Perlindungan Nelayan, Pembudidaya Ikan, dan Petambak Garam". Pelaksanaan perlindungan ini dilakukan dengan beberapa strategi sebagaimana diatur dalam Pasal 12 ayat (2) UU No. 7/2016. Adapun strategi perlindungan tersebut dilakukan melalui:

a. Penyediaan prasarana usaha pergaraman;

b. Kemudahan memperoleh sarana usaha pergaraman;

c. Jaminan kepastian usaha;

d. Jaminan risiko pergaraman;

e. Penghapusan praktik ekonomi biaya tinggi;

f. Pengendalian impor komoditas pergaraman;

g. Jaminan keamanan dan keselamatan; dan

h. Fasilitasi dan bantuan hukum.

Pada Pasal 12 ayat (3) UU No. 7/2016, diuraikan juga tentang strategi pemberdayaan dilakukan melalui: 
a. pendidikan dan pelatihan;

b. penyuluhan dan pendampingan;

c. kemitraan usaha;

d. kemudahan akses ilmu pengetahuan, teknologi, dan informasi; dan

e. penguatan Kelembagaan.

Pengaturan perlindungan terhadap petambak garam sebagaimana dijelaskan diatas yang telah diatur dalam UU No. 7/2016 menunjukkan kepedulian pemerintah akan nasib petambak garam. Berdasarkan undang-undang ini pula, diatur penghapusan praktik ekonomi biaya tinggi dan pengendalian impor komoditas pergaraman. Pada Pasal 36 UU No. 7/2016, diatur terkait penghapusan praktik ekonomi biaya tinggi dilakukan dengan (1) membebaskan biaya penerbitan perizinan yang terkait dengan penangkapan ikan, pembudidayaan ikan, pengolahan, dan pemasaran; dan (2) usaha pergaraman bagi nelayan kecil, pembudidaya ikan kecil, atau petambak garam kecil, termasuk keluarga nelayan dan pembudidaya ikan yang melakukan pengolahan dan pemasaran, membebaskan pungutan usaha perikanan atau usaha pergaraman, baik berupa pajak maupun retribusi bagi nelayan kecil, pembudi daya Ikan Kecil, atau petambak garam kecil, termasuk keluarga nelayan dan pembudi daya ikan yang melakukan pengolahan dan pemasaran.

Pengendalian impor diatur dalam Pasal 37 UU No. 7/2016, bahwa pemerintah pusatmengendalikan impor komoditas pergaraman. Pengendalian komoditas pergaraman tersebut dilakukan melalui penetapan tempat pemasukan, jenis dan volume, waktu pemasukan, serta pemenuhan persyaratan administratif dan standar mutu. Kebijakan pemerintah terkait impor garam dapat dilihat juga dalam Peraturan Pemerintah Nomor 9 Tahun 2018 tentang Tata Cara Pengendalian Impor Komoditas Perikanan dan Komoditas Pergaraman Sebagai Bahan Baku dan Bahan Penolong Industri dan Peraturan Menteri Perindustrian Nomor 34 Tahun 2018 tentang Tata Cara Pemberian Rekomendasi Impor Komoditas Pergaraman sebagai Bahan Baku dan Bahan Penolong Industri.

Pemerintah sudah saatnya untuk membentuk kebijakan-kebijakan lain dalam meningkatkan industri garam lokal dan kesejahteraan petambak garam sebagai implementasi dari UUD NRI Tahun 1945 dan UU No. 7/2016. Kebijakan ini berupa peraturan perundang-undangan seperti peraturan pemerintah dan peraturan presiden. Peraturan pemerintah berguna sebagai aturan pelaksana dari
UU No. 7/2016. Peraturan presiden memberikan ketentuan tentang pola peningkatan industri garam lokal yang harus dilakukan oleh pemerintah daerah. Pemeritah daerah juga perlu untuk membentuk peraturan daerah dan peraturan kepala daerah sebagai perwujudan hak-hak konstitusional bagi petambak garam. Hak-hak ini dapat terimplementasi jika ada regulasi seperti peraturan daerah dan peraturan kepala daerah dalam melindungi dan memberdayakan petambak garam.

\section{PENTINGNYA REGULASI PADA TINGKAT DAERAH}

Otonomi daerah telah memberikan kewenangan kepada daerah untuk mengelola daerahnya berdasarkan potensi lokal yang ada. Dalam otonomi daerah terdapat kewenangan untuk mengatur dan mengurus sendiri urusan pemerintahan dan kepentingan masyarakat lokal atau masyarakat daerah itu sendiri. Pelaksanaan otonomi daerah merupakan amanah dari Pasal 18, 18A dan 18B UUD NRI Tahun 1945. Pasal-pasal terkait otonomi daerah memberikan makna antara lain bawah pemerintah daerah dalam pelaksanaan otonomi daerah dapat membentuk peraturan daerah dan peraturan lainnya, pelaksanaan pemanfaatan sumber daya alam dan sumber daya lainnya perlu dilakukan secara adil dan selaras antara pemerintah pusat dan pemerintahan daerah, dan negara mengakui serta menghormati satuan-satuan pemerintahan daerah yang bersifat khusus atau bersifat istimewa serta mengakui dan menghormati kesatuan masyarakat hukum adat beserta hak-hak tradisionalnya. Namun dalam menjalankan otonomi daerah, pemerintahan daerah harus menyesuaikan dengan peraturan perundang-undangan yang dibentuk pemerintah.

Peraturan perundang-undangan yang telah dibentuk terkait otonomi daerah ini adalah UndangUndang Republik Indonesia Nomor 23 Tahun 2014 tentang Pemerintahan Daerah yang merupakan pengganti dari 2 (dua) undang-undang tentang Pemerintahan Daerah sebelumnya yaitu UndangUndang Nomor 22 Tahun 1999 dan Undang-Undang Nomor 32 Tahun 2004. Kedua undang-undang yang mengatur tentang pemerintahan daerah ini sudah tidak berlaku karena adanya perkembangan dan evaluasi dalam pelaksanaan otonomi daerah dan digantikan dengan Undang-Undang Nomor 23 Tahun 2014.

Salah satu perubahan yang signifikan dalam Undang-Undang Nomor 23 Tahun 2014 ini adalah 
dalam pengelolaan laut di mana Pemerintah Pusat telah telah menghilangkan pengelolaan laut pada tingkat daerah kabupaten/kota sehingga kewenangan ini berada pada Pemerintah Pusat. Perubahan yang sangat drastis terjadi pada sektor kelautan di mana UU Pemerintahan Daerah tidak menyisakan satu kewenanganpun kepada kabupaten/kota untuk pengelolaan sumber daya laut. Desentralisasi pengelolaan sumber daya laut hanya sampai di tingkat provinsi. Kabupaten/ kota memiliki kewenangan pada sektor perikanan seperti urusan pemberdayaan nelayan kecil. Urusan lainnya adalah pengelolaan dan penyelanggaraan Tempat Pelelangan Ikan (TPI) dan menerbitkan izin perikanan budidaya. Kewenangan yang diberikan ke provinsi banyak menyangkut perizinan selain pengawasan sumber daya perikanan (Dapu, 2016).

Kewenangan pengelolaan sumber daya kelautan pada pemerintah provinsi dapat menyebabkan pemerintah kabupaten/kota tidak maksimal dalam memberdayakan petambak garam. Pemerintah kabupaten/kota dapat saling menunggu kebijakan dari pemerintah provinsi dan pemerintah pusat. Pada sisi lain, kondisi petambak garam sangat memprihatinkan dan tidak dapat memperbaiki kondisi sosial ekonominya. Petambak garam pada umumnya menggantungkan hidup pada aktivitas pemanfaatan sumber daya laut dan pantai, dimana dalam pengelolaannya memerlukan investasi yang cukup besar. Selain itu, kondisi cuaca dan iklim yang tidak bersahabat serta mekanisme harga pasar yang tidak menentu. Perlu dicatat bahwa usaha produksi garam ini adalah paling lama 6 bulan dalam setahun namun rata-rata berjalan 5 bulan dalam setahun, tergantung kondisi cuaca yang ada (Ihsanudin, 2012).

Produksi garam tergantung pada cuaca khususnya pada musim kemarau, sehingga tidak dapat memberikan kontribusi yang maksimal sepanjang tahun. Artinya selama satu tahun garam hanya dapat diproduksi selama musim kemarau saja. Sementara pada musim penghujan para petambak garam tidak dapat menghasilkan garam secara maksimal atau bahkan para petambak garam akan kehilangan pekerjaan mereka. Menurut Ihsanuddin (2012), bagi hasil pendapatan petambak garam biasanya terdiri dari 30\% untuk petambak garam dan $70 \%$ untuk pemilik lahan dari total jumlah produksi yang diperoleh. Ada pula pembagiannya mencapai $50 \%$ untuk petambak dan $50 \%$ untuk pemilik lahan, hal ini terjadi ketika semua alat-alat produksi berasal dari petambak garam selaku penggarap (Ihsanudin, 2012).
Kebijakan yang dapat dibentuk oleh pemerintah daerah yaitu terkait penataan niaga garam yang selama ini mata rantai tata niaga garam rakyat dinilai sangat panjang dan justru menempatkan posisi petambak garam pada posisi yang lemah. Ketidakberdayaan petambak garam ini menimbulkan keprihatinan yang harus segera ditangani oleh pengambil kebijakan pada tingkat pusat sampai daerah. Posisi petambak garam dalam struktur pasar berada di antara dengan para perlaku usaha lainnya seperti pengepul, makelar, pemilik lahan serta distributor langsung. Hal ini dikarenakan adanya keterbatasan petambak garam atas sarana dan prasarana pengangkutan saat panen (Pangestu, 2018).

Petambak garam sebagai orang yang bekerja pada tambak-tambak garam perlu perlindungan yang nyata dari pemerintah daerah. Secara konstitusional sudah diuraikan diatas bahwa petambak garam mempunyai hak untuk mendapatkan bagian kesejahteraan dari hasil garam yang diolahnya, yaitu hasil kekayaan alam digunakan untuk sebesar-besarnya kemakmuran rakyat (Pasal 33 ayat (3) UUD NRI Tahun 1945) serta mendapatkan imbalan dan perlakuan yang adil dan layak hubungan kerja (Pasal 28D ayat (2) UUD NRI Tahun 1945).

UU No. 7/2016 telah memberikan kewenangan kepada pemerintah daerah untuk membentuk peraturan daerah sebagai tidak lanjut aturan dibawah peraturan perundang-undangan ini. Adapun kewenangan dan kewajiban pemerintah daerah dalam Undang-Undang Nomor 7 Tahun 2016, yaitu:

- Perencanaan dan penyelenggaraan perlindungan dan pemberdayaan terhadap petambak garam (Pasal 11 dan Pasal 16);

- Menyediakan prasarana usaha pergaraman yang meliputi lahan, saluran pengairan, jalan produksi, tempat penyimpanan garam, dan kolam penampung air (Pasal 18 ayat (6));

- Memberikan kemudahan petambak garam dalam memperoleh sarana pergaraman paling sedikit melalui penjaminan ketersediaan sarana usaha pergaraman (Pasal 21 ayat (1));

- Memberikan subsidi bahan bakar minyak atau sumber energi lainnya kepada petambak garam kecil (Pasal 24);

- Berkewajiban memberikan jaminan kepastian usaha dengan menciptakan kondisi yang menghasilkan harga garam 
yang menguntungkan bagi petambak garam yang dilakukan dengan mengembangkan sistem pemasaran komoditas pergaraman, jaminan pemasaran ikan melalui resi gudang, menyediakan sistem informasi harga garam secara nasional maupun international dan mengembangkan sistem rantai dingin (Pasal 25);

- Mengembangkan sistem pemasaran komoditas pergaraman melalui penyimpanan, transportasi, pendistribusian, dan promosi (Pasal 27);

- Berkewajiban memberikan pendampingan kepada penggarap tambak garam dalam membuat perjanjian kerja atau perjanjian bagi hasil (Pasal 28 ayat (3));

- Memberikan perlindungan petambak garam atas risiko yang dihadapi saat melakukan usaha pergaraman (Pasal 30 ayat (1));

- Memberikan fasilitas akses penjaminan kepada petambak garam guna peningkatkan kapasitas usaha pergaraman melalui perusahaan penjaminan (Pasal 31);

- Memberikan tugas kepada badan usaha milik daerah di bidang asuransi untuk melaksanakan asuransi pergaraman (Pasal 32) dan memfasilitasi setiap petambak garam menjadi peserta asuransi pergaraman (pasal 33);

- Bertanggung jawab memberikan jaminan keamanan bagi usaha pergaraman (Pasal 39 ayat (2));

- Berkewajiban melakukan fasilitasi dan memberikan bantuan hukum kepada petambak garam sesuai dengan ketentuan peraturan perundangundangan (Pasal 41);

- Bertanggung jawab atas pemberdayaan petambak garam (Pasal 44);

- berkewajiban memfasilitasi kemitraan usaha pergaraman (Pasal 50);

- berkewajiban memberikan kemudahan akses ilmu pengetahuan, teknologi, dan informasi (Pasal 52);

- melakukan pembinaan untuk pengembangan kelembagaan yang telah terbentuk. berkewajiban memfasilitasi bantuan pendanaan dan bantuan pembiayaan bagi petambak garam kecil, dan penggarap tambak garam (Pasal 61);

- Memberikan tugas kepada badan usaha milik daerah di bidang penjaminan untuk melaksanakan penjaminan kredit dan penjaminan pembiayaan terhadap petambak garam (Pasal 69); dan

- Melibatkan masyarakat dalam pemantauan dan pelaporan dengan memberdayakan potensi yang ada (Pasal 70 ayat (4)).

Kewenangan dan kewajiban pemerintah daerah di atas seharusnya menjadi acuan pemerintah daerah dalam membentuk peraturan daerah terkait dengan pemberdayaan dan perlindungan petambak garam. Peraturan daerah ini merupakan suatu peraturan yang dibentuk pada tingkat daerah untuk melaksanakan kewenangan yang telah diatur dalam undang-undang dan dalam hal tertentu dapat mengatur sendiri hal-hal yang tidak secara langsung diatur dalam undangundang (Fauzan, 2016). Pengaturan yang tidak diamanahkan langsung oleh undang-undang harus sesuai dengan kebutuhan dan karakter daerah masing-masing yang tetap tidak boleh bertentangan dengan peraturan perundang-undangan yang lebih tinggi.

Pulau Madura yang terdiri dari empat kabupaten hanya dua kabupaten yang memiliki peraturan daerah berkaitan dengan perlindungan petambak garam yaitu Kabupaten Sampang dan Pamekasan. Kedua kabupaten tersebut masingmasing memberikan perlindungan kepada petambah garam melalui Peraturan Daerah Kabupaten Sampang Nomor 1 Tahun 2016 (Perda Kabupaten. Sampang, No. 1/2016) tentang Perlindungan dan Pemberdayaan Petambak Garam dan Peraturan Daerah Kabupaten Pamekasan Nomor 5 Tahun 2019 (Perda Kabupaten. Pamekasan, No. 5/2019) tentang Perlindungan dan Pemberdayaan Nelayan, Pembudi Daya Ikan, dan Petambak Garam. Dua kabupaten lainnya yaitu Bangkalan dan Sumenep belum mempunyai produk hukum daerah berupa peraturan daerah yang berkaitan dengan perlindungan dan pemberdayaan petambak garam.

Kedua peraturan daerah yang melindungi petambak garam ini pun baru terbentuk dalam kurun waktu 4 (empat) tahun terakhir ini. Pembentukan peraturan daerah ini pun seakanakan hanya memenuhi formalitas pembentukan untuk menjalankan amanah Undang-Undang Nomor 7 Tahun 2016. Pada kedua kabupaten ini juga tidak ditemukan peraturan pelaksana sebagai bagian dari produk hukum daerah dan kebijakankebijakan lainnya untuk melaksanaan kedua peraturan daerah tersebut yaitu berupa peraturan bupatinya. Hal ini menunjukkan bahwa pemerintah 
daerah belum memprioritaskan industri garam sebagai salah satu skala prioritas di daerahnya.

Pentingnya produk hukum daerah yaitu peraturan daerah dan peraturan kepala daerah serta kebijakan daerah lainnya dalam melindungi petambak garam karena perlindungan dan pemberdayaan petambakgaram perlu tindakan yang nyata dan konkrit dari pemerintah daerah. Tindakan nyata dan konkrit ini diawali dengan pembentukan peraturan daerah dan peraturan pelaksananya seperti peraturan gubernur dan/atau peraturan bupati/wali kota. Peraturan daerah yang dibentuk oleh DPRD dan Pemerintah Daerah hanya mengatur hal-hal umum saja dan bukan teknis pelaksanaan. Peraturan kepala daerah merupakan peraturan yang berisi hal-hal teknis, detail dan dapat berupa pedoman dalam perlindungan dan pemberdayaan petambak garam. Perwujudan regulasi-regulasi ini, juga perlu dukungan sumber daya manusia dan anggaran. Sumber daya manusia diperlukan untuk memberdayakan petambak garam dan mengolah potensi sehingga lebih mengoptimalkan potensi sumber daya kelautannya. Anggaran digunakan untuk mendukung langkah-langkah strategis pemerintah daerah dalam rangka meningkatkan produksi garam lokal.

Perda Kabupaten Sampang, No. 1/2016 tentang Perlindungan dan Pemberdayaan Petambak Garam dan Perda Kabupaten Pamekasan, No. 5/2019 tentang Perlindungan dan Pemberdayaan Nelayan, Pembudi daya Ikan, dan Petambak Garam belum disertai dengan peraturan pelaksananya yaitu peraturan bupati atau pedoman pelaksanaan perlindungan dan pemberdayaan petambak garam. Peraturan pelaksana ini akan menjadi pedoman bagi dinas terkait seperti dinas perikanan pada daerah tersebut.

Kedua peraturan daerah yang telah terbentuk yaitu Perda Kabupaten Sampang, No. 1/2016 dan Perda Kabupaten Pamekasan, No. 5/2019 hampir mempunyai tujuan yang sama dengan UU Nomor 7 Tahun 2016. Adapun tujuan dari kedua peraturan daerah ini adalah:

- Mewujudkan kedaulatan dan kemandirian petambak garam dalam rangka meningkatkan taraf kesejahteraan, kualitas, dan kehidupan yang lebih baik;

- Menyediakan prasarana dan sarana petambak yang dibutuhkan dalam mengembangkan usaha Petambak garam;
- Memberikan kepastian usaha petambak garam; melindungi petambak dari fluktuasi harga, praktik ekonomi biaya tinggi, dan gagal panen;

- Meningkatkan kemampuan dan kapasitas petambak serta kelembagaan petambak garam dalam menjalankan usaha petambak garam yang produktif, maju, modern dan berkelanjutan; dan

- Menumbuh kembangkan kelembagaan pembiayaan petambak yang melayani kepentingan usaha petambak garam.

Khusus pada Peraturan Daerah Kabupaten Pamekasan ditambahkan pada tujuannya yaitu untuk melindungi dari risiko bencana alam, perubahan iklim, serta pencemaran; dan memberikan jaminan keamanan dan keselamatan serta bantuan hukum.

Kedua peraturan daerah tersebut berisikan muatan materi yang tidak jauh berbeda dengan UU No. 7/2016. Sebagaimana yang telah diuraikan di atas terkait kewenangan pemerintah daerah dalam perlindungan dan pemberdayaan petambak garam, maka peraturan daerah tersebut hampir sama dalam tujuan dan ruang lingkup pengaturan dengan Undang-Undang Nomor 7 Tahun 2016. Oleh karena itu, kedua peraturan daerah ini masih berisikan materi muatan yang umum dan tentunya tidak dapat diterapkan jika tidak ada peraturan kepala daerah. Peraturan kepala daerah ini sangat penting sebagai peraturan pelaksana agar normanorma dalam kedua peraturan daerah tersebut dapat dilaksanakan. Peraturan kepala daerah tentunnya berisi ketentuan-ketentuan teknis yang merupakan penjabaran dari norma yang umum dalam peraturan daerah.

Pasal 13 Perda Kabupaten Sampang No. 1/2016 menyatakan bahwa "Pemerintah daerah sesuai dengan kewenangannya bertanggungjawab atas Perlindungan Petambak Garam". Adapun terkait kewenangan bertanggung jawab atas perlindungan petambak garam tidak diuraikan lebih lanjut. Hal ini mengakibatkan ketidakjelasan bentuk dan mekanisme tanggung jawab tersebut. Demikian juga pada Peraturan Daerah Kabupaten Pamekasan Nomor 5 Tahun 2019, pada bab penyelenggaraan perlindungan yang dimulai dari Pasal 8 sampai Pasal 21 sama dengan Bab IV Penyelenggaraan Perlindungan dalam UndangUndang Nomor 7 Tahun 2016. Artinya peraturan daerah ini belum menjabarkan lebih rinci dari kewenangan yang diberikan oleh Undang-Undang Nomor 7 Tahun 2016. 
Berdasarkan pembahasan di atas, maka dalam pembentukan peraturan daerah tidak sekedar mengadopsi secara harfiah yang diperintahkan oleh peraturan di atasnya namun perlu untuk diterjemahkan apa yang dimaksud daeri kewenangan yang diberikan oleh peraturan yang lebih tinggi tersebut. Selain itu, peraturan daerah yang telah terbentuk masih memelurkan peraturan pelaksana seperti peraturan bupati sebagai pedoman operasional fungsional yang dilakukan oleh dinas terkait atau dalam rangka optimalisasi industri garam lokal.

Kebijakan daerah juga diperlukan sebagai serangkaian kegiatan yang sadar, terarah, dan terukur yang dilakukan oleh pemerintah yang melibatkan para pihak yang berkepentingan dalam bidang-bidang tertentu yang mengarah pada tujuan tertentu. Kebijakan ini dapat berbentuk pembentukan tim pemberdayaan petambak garam atau tim-tim lain yang terkait dalam mewujudkan amanah peraturan perundang-undangan yang lebih tinggi. Oleh karena itu, untuk efektivitas kebijakan publik diperlukan kegiatan sosialisasi, pelaksanaan dan pengawasan kebijakan (Ramdhani \& Ramdhani, 2017). Kebijakan daerah yang nantinya terbentuk harus dapat dirasakan dampaknya secara nyata oleh petambak garam maupun pelaku usaha industri garam. Pentingnya peraturan daerah tentang perlindungan dan pemberdayaan petambak garam, peraturan bupati/ wali kota terkait pedoman pelaksana perlindungan dan pemberdayaan petambak garam, dan pembentukan tim pemberdayaan petambak garam dikarenakan bahwa:

1. Pengaturan perlindungan petambak melalui Undang-Undang dan Peraturan Daerah masih bersifat umum karena fungsi dari UndangUndang dan Peraturan Daerah memang tidak mengatur secara teknis; dan

2. Untuk meningkatkan kualitas garam dengan alih teknologi dari negara-negara yang telah berhasil mengembangkan industri garam.

\section{IMPLIKASI KEBIJAKAN}

Berdasarkan penelitian yang dilakukan dapat disimpulkan bahwa perlindungan dan pemberdayaan petambak garam telah tersirat dalam UUD NRI Tahun 1945 dan telah ada peraturan perundang-undangan yang mengaturnya yaitu UU No. 7/2016. Undang-undang ini masih perlu dijabarkan dalam peraturan lainnya seperti peraturan menteri dan peraturan daerah. Peraturan menteri yang ada pun hanya terkait dengan ketentuan impor garam seperti Peraturan Menteri Perdagangan No. 63/2019 tentang Ketentuan Impor Garam, Peraturan Menteri Perindustrian nomor 34 tahun 2018 tentang Tata Cara Pemberian Rekomendasi Impor Komoditas Pergaraman sebagai Bahan Baku dan Bahan Penolong Industri. Pada tingkat daerah, pemerintah daerah perlu membentuk peraturan daerah tentang perlindungan dan pemberdayaan petambak garam juga perlu membentuk peraturan kepala daerah seperti peraturan bupati tentang pedoman pelaksanaan perlindungan dan pemberdayaan petambak garam.

Pembentukan regulasi pada tingkat daerah tersebut juga perlu didukung kebijakan dari pemerintah daerah sebagai bentuk aksi dan pengawasan pelaksanaan regulasi tersebut. Adapun regulasi yang diperlukan di daerah yaitu regulasi tentang perlindungan dan pemberdayaan petambak garam dan regulasi tentang optimalisasi industri garam lokal serta dapat pula pembentukan tim dalam melaksanakan pemberdayaan petambak garam di daerah.

\section{UCAPAN TERIMA KASIH}

Pertama, kami mengucapkan terima kasih kepada Lembaga Penelitian dan Pengabdian Kepada Masyarakat Universitas Trunojoyo Madura yang telah memberikan dana hibah penelitian Tahun 2019 sehingga sebagian hasil penelitian dapat kami tuangkan dalam artikel ini. Kedua, kami mengucapkan terima kasih kepada Balai Besar Riset Sosial Ekonomi Kelautan dan Perikanan, Badan Riset dan Sumber Daya Manusia Kelautan dan Perikanan Kementerian Kelautan dan Perikanan Republik Indonesia yang telah memberikan kesempatan kepada kami untuk mempresentasikan sebagian hasil penelitian kami dalam Seminar Nasional Sosial Ekonomi Kelautan dan Perikanan Tahun 2019.

\section{PERNYATAAN KONTRIBUSI PENULIS}

Encik Muhammad Fauzan merupakan konstributor utama dalam penulisan ini menganalisis dari aspek konstitusi dan evaluasi kebijakan yang ada di daerah. Indra Yulianingsih sebagai anggota berkonstribusi memberikan analisis dari aspek pemerintahan daerah dan kebijakan laut/maritim dan Azizah sebagai anggota berkonstribusi dalam menganalisis dari aspek kepentingan petambak garam. 


\section{DAFTAR PUSTAKA}

Amiruddin. \& Zainal, A. (2012). Pengantar Metode Penelitian Hukum (Cetakan ke-6). Jakarta, ID: PT. Rajagrafindo.

Arato, J. (2012). Constitutionality and constitutionalism beyond the state: Two perspectives on the material constitution of the United Nations. International Journal of Constitutional Law, 10(3), 627-659. DOI: https://doi.org/10.1093/ icon/mor079.

Asshiddiqie, J. (2010). Konstitusi Ekonomi. Jakarta, ID: Kompas.

Fauzan, E. M. (2016). Hukum Tata Negara Indonesia. Malang, ID: Setara Press.

Herman, S., Noor, E., \& Mulyadi, D. (2014). Identifikasi Faktor Kunci Krisis Pada Tataniaga Garam Konsumsi Di Indonesia Menggunakan Proses Jejaring Analitik (Analytic Network Process). Journal of Industrial Research (Jurnal Riset Industri), 8(3), 205-214.

Hutchinson, T. (2006). Researching and Writing In Law (second). Sydney, AUS: Thomson Legal \& Regulatory Limited.

Ihsanudin. (2012). Pemberdayaan Petani Penggarap Garam Melalui Kebijakan Berbasis Pertanahan. Activita, 2(1). DOI: https://doi.org/10.4018/978-14666-8342-6.ch010

Magdalena, D. (2018). Dinamika Hukum Perikanan Indonesia (Damai magdalena \& Fransisca Adelina Sinaga). 233, 251-262.

Mertokusumo, S. (2001). Penemuan Hukum Sebuah Pengantar. Yogyakarta, ID: Liberty.

Mustofa, E. T. (2015). Analisis Optimalisasi Terhadap Aktivitas Petani Garam Melalui Pendekatan Hilir Di Penambangan Probolinggo. Wiga, 5(1), 46-57.

Pangestu, R. G. (2018). Perlindungan Hukum terhadap Petambak Garam Rakyat Dikaitkan dengan Berlakunya Peraturan Pemerintah Nomor 9 Tahun 2018 tentang Tata Cara Pengendalian Impor untuk Komoditas Perikanan dan Pegaraman sebagai Bahan Baku dan Bahan Penolong I ndustri (Law Protecti. Dialogia Iuridica, 10(1), 77-95. DOI: https://doi.org/10.28932/ di.v10i1.1064.

Parwoto, P. (2018). Dampak Monopoli Garam Di Madura Pada Abad Xx. MOZAIK: Jurnal IImu-IImu Sosial Dan Humaniora, 7(1), 33-42. DOI: https://doi. org/10.21831/moz.v7i1.6182.

Paweka, Y. M. (2017). Analisis Natrium Dalam Air Laut Di Sekitar Pesisir Pantai Papua Dengan Metode Spektroskopi Serapan Atom. Indonesian Journal of Applied Sciences, 7(2), 19-24. DOI: https://doi. org/10.24198/ijas.v7i2.14987.
Peraturan Daerah Kabupaten Sampang Nomor 1 Tahun 2016 tentang Perlindungan dan Pemberdayaan Petambak Garam.

Peraturan Daerah Kabupaten Pamekasan Nomor 1 Tahun 2019 tentang Perlindungan dan Pemberdayaan Nelayan, Pembudidaya Ikan, dan Petambak Garam.

Peraturan Menteri Perindustrian Nomor 34 Tahun 2018 tentang Tata Cara Pemberian Rekomendasi Impor Komoditas Pergaraman sebagai Bahan Baku dan Bahan Penolong Industri.

Peraturan Menteri Perdagangan Republik Indonesia Nomor 63 Tahun 2019 tentang Ketentuan Impor Garam.

Peraturan Pemerintah Nomor 9 Tahun 2018 tentang Tata Cara Pengendalian Impor Komoditas Perikanan dan Komoditas Pergaraman sebagai Bahan Baku dan Penolong Industri.

Prihantini, C. I., Syaukat, Y., \& Fariyanti, A. (2016). Pola Bagi Hasil Usaha Garam Rakyat di Kabupaten Pamekasan, Jawa Timur. Jurnal Agribisnis Indonesia. Journal of Indonesian Agribusiness, 4(1),1-16.DOl:https://doi.org/10.29244/ jai.2016.4.1.1-16.

Prihantini, C. I., Syaukat, Y., \& Fariyanti, A. (2017). Perbandingan Pola Bagi Hasil Dalam Usaha Garam Rakyat di Kabupaten Pamekasan, Jawa Timur. Jurnal Kebijakan Sosial Ekonomi Kelautan dan Perikanan, 7(1), 77-90. DOI: http://dx.doi. org/10.15578/jksekp.v7i1.4997.

Ramdhani, A., \& Ramdhani, M. A. (2017). Konsep umum pelaksanaan kebijakan publik. Jurnal Publik, 11(1), 1-12. DOI: https://doi.org/10.1109/ ICMENS.2005.96

Samsiyah, N., Moelyaningrum, A. D., \& Trirahayu Ningrum, P. (2019). Garam Indonesia Berkualitas: Studi Kandungan Logam Berat Timbal $(\mathrm{Pb})$ Pada Garam [The Quality of Indonesia Salt: Study of Heavy Metal Lead (Pb) Levels in the Salt]. Jurnal IImiah Perikanan Dan Kelautan, 11(1), 43. DOI: https://doi.org/10.20473/jipk. v11i1.11058.

Soesilowati, E., \& Garam, P. (2013). Penguatan Industri Garam Nasional Melalui Perbaikan Teknologi Budidaya Dan Diversifikasi Produk. Sainteknol, 11(2), 129-142. DOI: https://doi.org/10.15294/ sainteknol.v11i2.5572.

Suratman, \& Dillah, P. (2012). Metode Penelitian Hukum. Alfabeta.

Undang-Undang Dasar Negara Republik Indonesia Tahun 1945.

Undang-Undang Republik Indonesia Nomor 43 Tahun 2008 tentang Wilayah Negara.

Undang-Undang Republik Indonesia Nomor 23 Tahun 2014 tentang Pemerintahan Daerah. 
Undang-Undang Republik Indonesia Nomor 32 Tahun 2014 tentang Kelautan.

Undang-Undang Republik Indonesia Nomor 7 Tahun 2016 tentang Perlindungan dan Pemberdayaan Nelayan, Pembudi Daya Ikan, dan Petambak Garam.

Yaqin, A. (2007). Legal Research and Writing. Lexis Nexis.

Dapu, Y. M. (2016). Implikasi UU No. 23 Tahun 2014 Terhadap Kewenangan Urusan Pemerintahan Daerah Di Bidang Kelautan Dan Perikanan. Lex Et Societatis, 4(8).

Zainuri, M., Anam, K., \& Susanti, A. P. (2016). Hubungan Kandungan Natrium Chlorida $(\mathrm{NaCl})$ dan Magnesium (Mg) dari Garam Rakyat di Pulau Madura. Prosiding Seminar Nasional Kelautan, 167-172.

Zein, Y. A. (2016). Politik Hukum Pengelolaan Wilayah Perbatasan Berbasis Pemenuhan Hak Konstitusional Warga Negara. Jurnal Hukum IUS QUIA IUSTUM, 23(1), 97-122. DOI: https://doi. org/10.20885/iustum.vol23.iss1.art6. 